P-ISSN: 2615-1723

E-ISSN: 2615-1766

Oktober 2018
Jurnal Riset Pendidikan Dasar

01 ( 2), ( 2018) 152-157

Submitted: Agustus, Accepted: September, Published: Oktober

\title{
HASIL BELAJAR SISWA PADA MATERI MATERI OPERASI HITUNG CAMPURAN PEMBELAJARAN DENGAN MODEL STAD
}

\author{
Mustahiqul Jannah*, Joko Sulianto \\ Program Studi Pendidikan Guru Sekolah Dasar, Fakultas Ilmua Pendidikan \\ Universitas PGRI Semarang, Indonesia \\ E-mail: mustahiqulimus@gmail.com
}

\begin{abstract}
Abstrak
Penelitian ini bertujuan untuk mendeskripsikan model pembelajaran STAD (Student Teams Achievemen Division) pada materi operasi hitung campuran di SD. Penelitian ini menggunakan pendekatan kuantitatif. Adapun subjek penelitian ini adalah 24 siswa kelas III A dan 25 siswa kelas III B SD Negeri Dongos 04 Jepara. Penggunaan model pembelajaran STAD meningkatkan hasil belajar siswa pada materi operasi hitung campuran
\end{abstract}

Kata Kunci:Hasil Belajar, Operasi Hitung Campuran, Model STAD

\section{STUDENT LEARNING OUTCOMES IN MATERIAL FOR OPERATIONS COMPUTE \\ LEARNING MIXTURES WITH THE STAD MODEL}

\begin{abstract}
This study aims to describe the learning model of STAD (Student Teams Achievemen Division) on the material of mixed count operation in $S D$. This research uses quantitative approach. The subject of this research are 24 students of class III A and 25 students of class III B SD Negeri Dongos 04 Jepara. Result: the use of STAD learning model improves student learning outcomes on mixed count material
\end{abstract}

Keywords: Learning Outcomes, Mixed Count Operation, STAD Model

\section{PENDAHULUAN}

Sesuai dengan amanat Peraturan Pemerintahan Nomor 19 Tahun 2005 tentang Standar Nasional Pendidikan, salah satu standar yang harus dikembangkan adalah standar proses. Standar proses adalah standar nasional pendidikan yang berkaitan dengan pelaksanaan pembelajaran pada satuan pendidikan untuk mencapai kompetensi lulusan. Standar proses berisi kriteria minimal proses pembelajaran pada satuan pendidikan dasar dan menengah di seluruh wilayah hukum Negera Kesatuan Republik Indonesia. Standar proses ini berlaku untuk jenjang pendidikan dasar dan menengah pada jalur formal, baik pada sistem paket maupun pada sistem kredit semester. Standar proses meliputi perencanaan pembelajaran, pelaksanaan proses pembelajaran, penilaian hasil pembelajaran dan pengawasan proses pembelajaran untuk 
terlaksananya proses pembelajaran yang efektif dan efisien.

Menurut Rusman (2012: 58) proses pembelajaran merupakan suatu proses yang mengandung serangkaian perbuatan guru dan siswa atas hubungan timbal balik yang berlangsung dalam situasi edukatif untuk mencapai tujuan tertentu, dimana dalam proses tersebut terkandung multiperan guru. Guru merupakan ujung tombak keberhasilan kegiatan pembelajaran di sekoah yag terlibat langsung dalam merencanakan dan melaksanakan kegiatan pembelajaran. Kualitas kegiatan pembelajaran yang dilakukan sangat bergantung pada perencanaan dan pelaksanaan proses pembelajaran yang dilakukan guru. Tugas guru bukan semata-mata mengajar (teacher centered), tapi lebih kepada membelajarkan siswa (children centered). Selain itu guru harus menguasai semua materi pelajaran yang akan diajarkan kepada siswa salah satunya matematika. Dalam proses pembelajaran matematika, siswa masih pasif dikarenakan pembelajaran masih berpusat pada guru. Dalam pembelajaran matematika yang membutuhkan pemahaman konsep atau pemahaman matematis salah satunya yaitu operasi hitung campuran dalam mengerjakan operasi hitung campuran siswa diharapkan mampu memahami konsep dasar terlebih dahulu.

Berdasarkan data yang ada dilapangan hasil belajar matematika operasi hitung campuran siswa rendah. Hal itu dinuktikan dengan rata-rata 64 yang belum mememnuhi kriteria minimum yaitu 67 .

Menurut Heruman dalam Kurniawati (2016: 24) mengemukakan "operasi hitung campuran adalah operasi atau pengerjaan hitungan yang melibatkan lebih dari dua bilangan dan lebih dari satu operasi". Operasi hitung campuran meliputi penjumlahan, pengurangan dan perkalian serta pembagian. Penyelesaian pengerjaan operasi hitung harus memperhatikan tanda operasi hitungnya terlebih dahulu.
Selain itu dalam proses pembelajaran, model pembelajaran yang digunakan belum bervariatif. Satu model pembelajaran kooperatif yaitu tipe Student Teams Achievement Division yang selanjutnya disingkat STAD ini merupakan salah satu tipe dari model pembelajaran kooperatif dengan menggunakan kelompok kecil. Menurut Slavin (2010: 143) mengatakan bahwa STAD terdiri atas lima komponen-komponen utama yaitu presentasi kelas, tim, kuis, skor kemajuan individual, dan rekognisi tim. Setiap kelompok terdiri dari 4 sampai 5 siswa berdasarkan tingkat kecerdasan, jenis kelamin, dan suku yang berbeda. Sebelumnya guru mempresentasikan materi pelajaran kepada seluruh siswa, kemudian siswa membentuk kelompok untuk memecahkan suatu masalah secara bersamasama dan memastikan bahwa seluruh anggota kelompoknya mampu menguasai materi Matematika operasi hitung campuran.

Menurut Rusman (2012: 215) langkahlangkah pembelajaran kooperatif model STAD sebagai berikut:

a. Fase 1 Penyampaian Tujuan dan Motivasi

Menyampaikan tujuan pelajaran yang ingin dicapai pada pembelajaran tersebut dan memotivasi siswa untuk belajar.

b. Fase 2 Pembagian kelompok

Siswa dibagi ke dalam bebeapa kelompok, di mana setia kelompoknya terdiri dari 4-5 siswa yang memprioritaskan heterogenitas (keragaman) kelas dalam prestasi akademik, gender/jenis kelamin, ras atau etnik.

c. Fase 3 Presentasi dari Guru

Guru menyampaikan materi pelajaran dengan terlebih dahuu menjelaskan tujuan pelajaran yang ingin dicapai pada pertemuan pertemuan tersebut serta pentingnya pokok bahasan tersebut dipelajari. Guru memberian motivasi siswa agar dapat belajar dengan aktif dan kreatif. Di dalam proses pembelajaran guru dibantu oleh media, demonstrasi, pertanyaan atau masalah nyata yang tejadi dalam kehidupan sehari-hari. Dijelaskan juga tentang 


\section{Jurnal Riset Pendidikan Dasar, 01 ( 2), Oktober 2018 (152-157)}

Mustahiqul Jannah, Joko Sulianto

keterampilan dan kemampuan yang diharapkan dikuasai siswa, tugas dan pekerjaan yang harus dilakukan serta caracara mengerjakannya.

d. Fase 4 Kegiata Belajar dalam Tim (tim kerja)

Siswa belajar dalam kelompok yang telah dibentuk. Guru meyiapkan lembaran kerja sebagai pedoman bagi kerja kelompok, sehingga semua anggota menguasai dan masing-masing memberikan kontribusi. Selama tim bekerja, guru melakukan pengamatan, memberikan bimbingan, dorongan dan bantuan bila diperlukan. Kerja tim ini merupakan ciri terpenting dari STAD.

e. Fase 5 Kuis (Evaluasi)

Guru mengevaluasi hasil belajar melalui pemberian kuis tentang materi yag dipelajari dan juga melakukan penilaian terhadap presentasi hasil kerja masingmasing kelompok. Siswa diberikan kursi secara individual dan tidak dibenarkan bekerja sama. $\mathrm{Ni}$ dilakukan untuk menjamin siswa secara individu bertanggung jawab kepada diri sendiri dalam memahami bahan ajar tersebut.

f. Fase 6 Penghargaan Prestasi Tim

Setelah pelaksanaan kuis, guru memeriksa hasil kerja siswa dan diberikan angka dengan rentang 0-100. Selanjutnya pemberian penghargaan atas keberhasilan kelompok.

Isjoni (2014: 51) mengatakan bahwa "STAD merupakan salah satu tipe kooperatif yang menekankan pada adanya aktivitas dan interaksi diantara siswa untuk saling memotivasi saling membantu dalam menguasai materi pelajaran guna mencapai prestasi yang maksimal". Dengan menggunakan model pembelajaran STAD Interaksi sosial yang terbangun dalam kelompok, dengan sendirinya siswa belajar dalam bersosialisasi dengan lingkungannya (kelompok).

Selaras dengan teori belajar Vygotsky lebih menekankan pada aspek sosial dari pembelajaran. Menrut Vygotsky proses pembelajaran akan terjadi jika anak bekerja dalam menangani tugas-tugas yang belum dipelajari, namun tugas-tugas tersebut masih masih berasa dalam jangkauan mereka disebut zoom of proximal development, yakni daerah tingkat perkembangan sedikit di atas daerah perkembangan seseorang sat ini (Trianto, 2007: 39). Dengan penggunaan model STAD siswa siswa dibentuk tiap kelompok untuk berdiskusi dan saling bekerjasama. Dalam kegiatan berkelompok siswa mampu menjalin komunikasi yang baik dengan anggota kelompok yang lain, hal itu menunjukkan ada interaksi sosial yang terjalin.

Penggunaanmodel pembelajaran STAD pada mata pelajaran matematika materi operasi hitung campuran diharapkan dapat bermanfaat kepada proses pembelajaran yang meningkatkan hasil belajar siswa. Hal ini dapatdiperkuat dengan adanya penelitian terdahulu Indah Sari yang berjudul pengaruh pembelajaran kooperatif STAD terhadap hasil belajar siswa materi elastisitas kelas XI SMAN 1 GedanganPenelitian ini bertujuan untuk mendeskripsikan pengaruh pembelajaran kooperatif tipe STAD (Student Team Achievement Division) terhadap hasil belajar siswa pada materi pokok elastisitas kelas XI. Pembelajaran kooperatif merupakan suatu bentuk model pembelajaran yang menuntut kerjasama siswa dan saling ketergantungan dalam struktur tugas, tujuan, dan penghargaan. Populasi dari penelitian ini adalah siswa kelas XI di SMAN 1 Gedangan dengan jenis penelitian eksperimen kuantitatif dengan desain True Experimental. Bentuk dari True Experimental Design yang dipilih adalah Kontrol Group Pretest Post-test Design. Berdasarkan hasil penelitian dengan menggunakan uji hipotesis diperoleh bahwa kelas eksperimen yang menerapkan model pembelajaran kooperatif tipe STAD leih baik daripada kelas kontrol.

\section{METODE}




\section{Jurnal Riset Pendidikan Dasar, 01 ( 2), Oktober 2018 (152-157)}

Mustahiqul Jannah, Joko Sulianto

Metode penelitian ini menggunakan metode pendekatan kuantitatif. Desain penelitian ini menggunakan penelitian True Experimental Design dengan bentuk desain eksperimen Pretest-posttestControl Group Design. Populasi dalam penelitian ini yaitu seluruh siswa SD Negeri Dongos 04 Jepara. Sampel dalam penelitian ini yaitu siswa kelas III A yang berjumlah 24 yang dijadikan sebagai kelas eksperimen menggunakan model STAD dan kelas III B yang berjumlah 25 sebagai kelas kontrol menggunakan pembelajaran konvensional

Teknik pengumpulan data pada penelitian ini adalah melalui observasi, dokumentasi dan tes. Observasi pada penelitian ini penulis melakukan pengamatan dan wawancara dengan guru kelas III SD Negeri Dongos 04 Jepara. Dokumentasi padapenelitian ini digunakan untuk mengumpulkan data siswa sebagai pembuktian perbandingankelas kontrol dan eksperimen. Metode tes ini digunakan peneliti untuk mengukur hasil belajar kognitif siswa materi operasi hitung campuran.

Teknik analisis instrumen pada penelitian ini menggunakan analisis validitas, reliabilitas, taraf kesukaran dan daya pembeda. Kemudian data yang telah dikumpulkan selanjutnya dilakukan pengujian hipotesis menggunakan uji t. Sebelum dilakukan pengujian hipotesis terlebih dahulu dilakukan uji matching group dan uji normalitas.

\section{HASIL DAN PEMBAHASAN}

\section{Hasil Pretest}

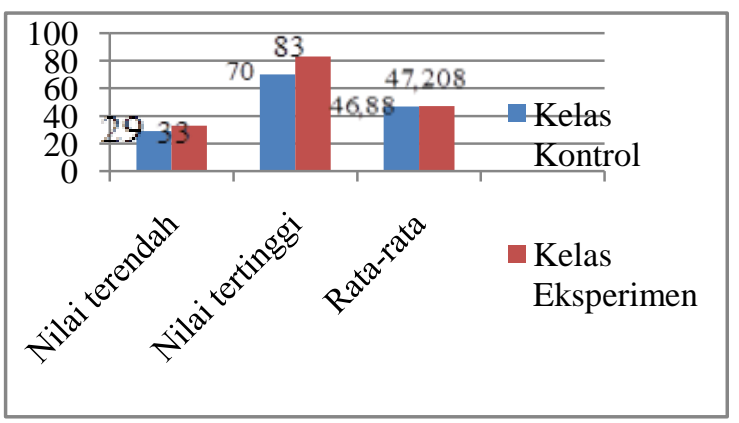

Gambar 1. Grafik Perbandingan Hasil Pretest
Berdasarkan gambar 1 Hasil pretest kelas eksperimen dan kelas kontrol tidak terlalu jauh berbeda. Rata-rata kelas eksperimen 47,208 dan kelas kontrol 46,88 terlihat bahwa hasil pretest kelas eksperimen dan kelas kontrol belum mencapai ketuntasan belajar yaitu 67 .

\section{Hasil Posttest}

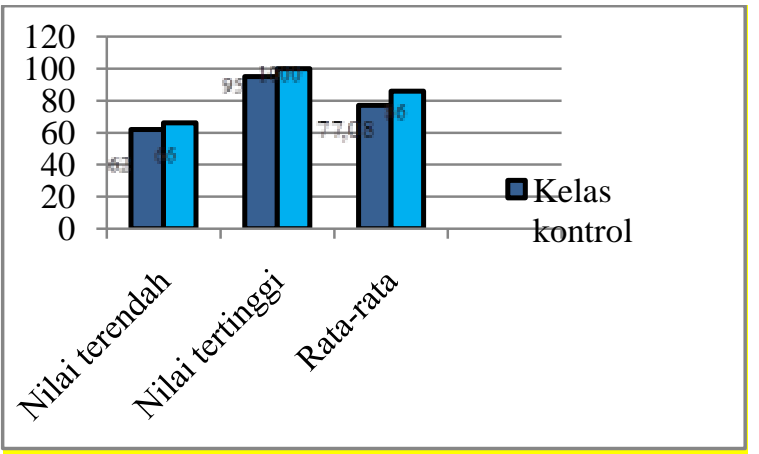

Gambar 2. Grafik Pebandingan Hasil Belajar Posttest

Berdasarkan gambar 2 Hasil posttest kelas eksperimen dan kelas kontrol diketahui bahwa nilai rata-rata kelas eksperimen 86 dan rata-rata kelas kontrol 77,08. Hal ini menunjukkan rata-rata kelas ekserimen lebih dari kelas kontrol.

Berdasarkan hasil analisis awal uji normalitas data awal rata-rata kelas kontol 46,88 dan kelas eksperimen 47,208 dapat dijelaskan bahwa denga taraf nyata $\alpha=5 \%$ dan $\mathrm{N}=24$ pada kelas eksperimen diperoleh $\mathrm{L}_{\text {hitung }}=0,17893, \mathrm{~L}_{\text {tabel }}=0,180$ maka $\mathrm{H}_{0}$ diterima karena $\mathrm{L}_{\text {hitung }}<\mathrm{L}_{\text {tabel }}$ yaitu $0,17893<$ 0,180 . Pada kelas kontrol dengan taraf nyata $\alpha$ $=5 \%$ dan nilai $\mathrm{N}=25$ diperoleh $\mathrm{L}_{\text {hitung }}=$ 0,1574 dan $\mathrm{L}_{\text {tabel }}=0,173$ maka $\mathrm{H}_{0}$ diterima karena $\mathrm{L}_{\text {hitung }}<\mathrm{L}_{\text {tabel }}$ yaitu $0,1574<0,173$. Sehingga dapat diketahui kedua kelas tersebut berdistribusi normal.

Hasil Posttest diperoleh rata-rata kelas kontrol 77,08 dan kelas Eksperimen 86 dilakukan dengan menggunakan uji Lilifors pada kelas eksperimen dengan taraf nyata $\alpha=$ $5 \%$ dan $\mathrm{N}=24$ pada diperoleh $\mathrm{L}_{\text {hitung }} 0,11887$, $\mathrm{L}_{\text {tabel }} \quad 0,180$ maka $\mathrm{H}_{0}$ diterima karena $\mathrm{L}_{\text {hitung }}<$ $\mathrm{L}_{\text {tabel }}$ yaitu $0,11887<0,180$, pada kelas kontrol Copyright $@ 2018$, JRPD, ISSN 2615 - 1723 (Print), ISSN 2615 - 1766 (Online) 
diperoleh $\mathrm{L}_{\text {hitung }} 0,1052, \mathrm{~L}_{\text {tabel }} 0,173$ maka $\mathrm{H}_{0}$ diterima karena $\mathrm{L}_{\text {hitung }}<\mathrm{L}_{\text {tabel }}$ yaitu $0,1052<$ 0,173 hal tersebut menunjukkan bahwa kedua kelas berdistribusi normal.

Berdasarkan hasil penelitian menunjukkan bahwa pembelajaran pada kelas eksperimen lebih baik daripada kelas kontrol. Dikarenakan adanya keefektifan model STAD terhadap hasil belajar siswa kelas III SD Negeri Dongos 04 Jepara. Hal ini dapat dilihat dari hasil rata-rata kelas eksperimen yaitu 86 , dengan ketuntasan 95\%, hanya ada 1 satu siswa yang tidak tuntas dari KKM yang telah ditentukan yaitu 67 sedangkan 23 siswa lainnya sudah tuntas. Sedangkan rata-rata kelas kontrol yaitu 77,08 dengan ketuntasan $80 \%, 5$ siswa yang tidak tuntas dari KKM sedangkan 20 siswa lainnya sudah tuntas.

Sesuai dengan pendapat Kurniasih dan Berlin Sani (2015: 22-23) menyampaikan model STAD sangat efektif, karena proses pembelajarannya dalam kelompok siswa dituntut untuk aktif sehingga dengan model STAD siswa dengan sendirinya akan percaya diri dan meningkat kecakapan individunya. Dengan dibentuk kelompok siswa diajarkan untuk saling mengerti dengan materi yang ada, sehingga siswa saling memberitahu dan mengurangi sifat kompetitif.

Berdasarkan uji t-tes posttest dua sampel membandingkan hasil belajar matematika dikelas eksperimen menggunakan model STAD dan kelas kontrol menggunkan pembelajaran konvensional apakah sama atau tidak. Untuk menghitung menggunakan nilai posttest kelas eksperimen dan nilai posttest kelas kontrol. Berdasarkan hasil perhitungan diperoleh $\mathrm{dk}(\mathrm{n} 1+\mathrm{n} 2-2)=24+25-2=47$ dan taraf nyata $\alpha=5 \%$ dapat diperoleh thitung $=$ $3,62070>$ ttabel $=2,014$ maka $\mathrm{H}_{0}$ ditolak dan Ha diterima.Dapat disimpulkan bahwa hasil belajar matematika kelas eksperimen dan kontrol tidak sama, jadi hasil belajar siswa yang menggunakan model pembelajaran STAD lebih tinggi dari pada hasil belajar siswa yang menggunakan pembelajaran konvensional. Selain itu dilakukan uji t satu pihak untuk menghitung uji ketuntasan belajar siswa kelas eksperimen diperoleh 95\% siswa tuntas. Sehingga model STAD efektif terhadap hasil belajar Matematika materi operasi hitung campuran siswa kelas III SD Negeri Dongos 04 Jepara artinya hasil belajar Matematika mater operasi hitung campuran kelas eksperimen lebih baik dari pada hasil belajar pada siswa kelas kontrol. Hal ini sejalan dengankajian penelitian yang relevan yang dilakukan Mustika,dengan judul pengaruh pembelajaran kooperatif STAD terhadap hasil belajar ditinjau dari motivasi belajar pada pembelajaran matematika siswa kelas IV SD Saraswati Tabanan penelitian ini bertujuan untuk mengetahui pengaruh motivasi belajar terhadap hasil matematika siswa kelas IV SD Saraswati Tabanan. Penelitian ini menggunakan metode eksperimen semu dengan menggunakan rancangan eksperimen semu dengan menggunakan post-test only kontrol group design yang melibatkan sampel sebanyak 80 orang yang dipilih secara acak. Data dikumpulkan melalui test dan dianalisis menggunakan analisis varians (anava) dua jalur. Hasil penelitian menunjukkan model pembelajaran kooperratif tipe STAD berdampak lebih baik secara signifikan terhadap hasil belajar Matematika dibandingkan dengan hasil belajar dengan model konvensional.

Hasil belajar siswa kelas eksperimen yang menggunakan modelSTAD lebih baik daripada siswa kontrol karena siswa lebih pahamterhadap materi yang dipelajari karena terlibat langsung dalam pembelajaran sehingga bermakna bagi diri siswa serta siswa aktif dalam proses pembelajaran. Cara menerapkan model STAD terkesan jauh lebih menyenangkan dengan adanya pengalaman langsung oleh siswa, sehingga meningkatkankemampuan untuk bekerja sama dan bersosialisasi antar siswa.

Dalam penelitian ini ada beberapa kendala yang dialami peneliti. Kelemahan yang pertama yaitu, dalam melaksanakan model pembelajaran ini adalah menjaga Copyright $\odot 2018$, JRPD, ISSN 2615 - 1723 (Print), ISSN 2615 - 1766 (Online) 
semangat belajar bagi siswa yang mempunyai tingkat kemampuan akademik yang tinggi dibandingkan anggota kelompok yang lain, karena lebih berdominan dan selalu diadalkan dalam mengajarkan anggota kelompok yang belum mampu memahami materi yang dipelajarai. Hal ini menunjukkan tidak adanya kompetisi bagi siswa yang pandai dengan aggota kelompokknya sehingga semangat belajarnya dapat menurun.

Kedua, yaitu waktu. Dalam pelaksanaannya, model STAD didalamnya yaitu membentuk kelompok, dalam membentuk kelompok membutuhkan waktu yang cukup banyak. Peserta didik membutuhkahkan waktu untuk merubah posisi tempat duduk secara berkelompok.

Selain keterbatasan-keterbatasan di atas, beberapa kelebihan yang didapatkan adalah: Pertama, penerapan model pembelajaran STAD sesuai pembelajaran Matematika di sekolah dasar. Model ini terjadi interaksi soasial yang terbangun dalam kelompok, dengan sendirinya siswa belajar dalam bersosialisasi dengan anggota kelompok.

Kedua, dengan menerapkan model STAD siswa diajarkan untuk saling membantu teman jika mengalami kesulitas dalam menyelesaikan soal. Didalam kelompok terdiri dari kelompok yang memiliki kemampuan heterogen.

Dari kelemahan dan kelebihan di atas, peneliti berharap model STAD ini dapat dijadikan alternatif baru dalam pembelajaran terutama Matematika. Dengan demikian, guru tidak hanya menggunakan satu model saja, tetapi bervariasi.

\section{SIMPULAN}

Berdasarkan uraian diatas dapat disimpulkan Pembelajaran menggunakan model STAD meningkatkan hasil belajar matematika materi operasi hitung campuran

Saran Penelitian ini diharapkan dapat memberikan masukan kepada guru- guru untuk menerapkan model pembelajaran STAD
(Student Teams Achievement Division) sebagai salah satu alternatif model pembelajaran, karena model pembelajaran ini efektif untuk meningkatkan hasil belajar siswa

\section{DAFTAR PUSTAKA}

Departemen Pendidikan Nasional, 2005. Peraturan Pemerintah Nomor 19 Tahun2005, tentang Standar Nasional Pendidikan. Jakarta: Depdiknas.

Isjoni. 2014. Coopertive Learning Mengembangkan Kemampuan Belajar Berkelompok. Bandung: Alfabeta.

Indah Sari, Abdullah Aziz. 2014. Pengaruh Pembelajaran Kooperatif STAD Terhadap Hasil Belajar Siswa Materi Elastisitas Kelas XI SMAN 1 Gedangan. http://jurnalmahasiswa.unesa.ac.id/artic le/9767/32/article.pdf. Jurnal. Diakses 8 November 2018.

Kuruniawati, Eri. 2016. "Keefektifan Model Pembelajaran CTL dan STAD terhadap Hasil Belajar Matematika Kelas V SDN Sendangguwo 01 Semarang".Skripsi. Semarang: Universitas PGRI Semarang.

Kurniasih, Imas dan Berlin Sani. 2015. Ragam Pengembangan Model Pembelajaran untuk Peningkatan Profesionalitas Guru. Yogyakarta: Kata Pena.

Mustika, Christianti Aniek. 2013.Pengaruh Pembelajaran Kooperatif STAD Terhadap Hasil Belajar Ditinjau dari Motivasi Belajar Paada Pembelajaran Matematika Siswa Kelas IV SD Saraswati Tabanan. http://pasca.undiksha.ac.id/ejournal/in dex.php/jurnal_pendas/article/downloa d/669/454. Jurnal. Diakses 7 November 2017.

Rusman. 2012. Seri Manajemen Sekolah Bermutu Model-model Pembelajaran Mengembangkan Profesionalisme Guru. Bandung: PT Raja Grafindo Persada.

Slavin, Robert E, 2010. Coopertive Learning Teori, Riset dan Praktik. Bandung: Nusa Media.

Trianto. 2007. Model-model pembelajaran Inovatif Berorientasi Konstruktivistik. Jakarta: Prestasi Pustaka Publisher. 